\title{
Hjartemaskinar og husnummer. Femåringars eigeninitierte tekstar - bruk og retorisitet
}

\author{
Gudrun Kløve Juuhl \\ Høgskulen i Volda
}

\section{Samandrag}

Også born som enno ikkje er innlemma i det formelle lese- og skriveopplæringssystemet, skaper tekstar som har kommunikativ funksjon og verdi. Likevel vert ofte tekstproduksjonen til born, også barnehageborn, studert med utdanningssystemet sine føremål om læring og vurdering som premiss. Slike studiar seier lite om dei kommunikative aspekta ved borns tekstproduksjon.

Denne artikkelen undersøkjer fem tekstar av fem femåringar og kva kommunikative samanhengar tekstane inngår i, og diskuterer med utgangspunkt i det korleis det er rimeleg å forstå dei som ytringar. Undersøkinga tek utgangspunkt i den etnografiske New literacy studies-tradisjonen, som vert supplert med aktør-nettverk-teori og retorisk teori.

Sjølv om desse borna i varierande grad meistra skriftspråket, laga alle tekstar som vart brukte til å handla sosialt med. Ei viktig handling var namngjeving. Fleire tekstar utgjorde artefaktar i leik. Det varierte i kva grad tekstane var sentrale i dei sosiale handlingane dei var del av. Dette viser behovet for modellar av tekst og kontekst som ikkje som utgangspunkt set teksten i sentrum. Resultata i denne studien skil seg også frå tidlegare studiar av borns tekstar ved at pragmatisk funksjonalitet framstår som viktigare enn indre kompleksitet, og ved få spor av henvending til ein lesar. Dette viser at born sine tekstar er meir mangfaldige enn tidlegare forsking har vist, og at det å studera dei med eit etnografisk utgangspunkt kan bidra til at ein fangar opp ein større del av mangfaldet.

Nøkkelord: Barns fritidstekstar; literacy i kvardagen; tekstanalyse; skriving utanfor skulen; skriving før skulealder

\begin{abstract}
Heartmachine and house numbers. Five-year-olds' self initiated texts - uses and rhetoric

Even children not yet enrolled in formalized education create texts with communicative functionality and value. However - children's texts are often studied with the education system's aim of learning and assessment as a premise. Such studies have little to tell about the communicative aspects of the texts.

The present article explores five texts by five five-year-olds and what communicative contexts the texts are part of, and discusses how to understand them as utterances. The exploration starts
\end{abstract}

^Korrespondanse: Gudrun Kløve Juuhl, e-post: gudrun.klove.juuhl@hivolda.no 


\section{G. K. fuuhl}

from the ethnographical tradition of New Literacy studies, Supplied with actor-network theory and rhetorical theory.

Even though the children's mastering of writing varied, all of them produced texts used in social action. One important action was naming. Several texts were artifacts for play. It differed to what extent the texts were central in the social actions they were part of. This shows the need for models of texts and context that doesn't place the texts in the middle as default.

The results of this study deviates from earlier studies of children's texts in that pragmatic functionality seemed more important than textual complexity, and that they were not characterized by addressing a reader. This shows that children's texts are more diverse that earlier research has shown, and to study them from an ethnographic angle may catch a greater part of this diversity.

Keywords: Children's leisure time texts; children's vernacular literacy; text analysis; writing out of school; writing before school

Guest editor: Maja Michelsen

Received: December, 2019; Accepted: October, 2020; Published: December, 2020

\section{Innleiing}

Born brukar tekstar til å kommunisera og handla sosialt, også før dei meistrar skriftspråket. Mange studiar av born sine tekstar er knytte til utdanningsinstitusjonen og handlar om kva borna meistrar og ikkje, og korleis ein kan hjelpa dei til å verta meir kompetente tekstprodusentar (Schultz, Hull \& Higgs, 2016). I slike studiar vert tekstane gjerne forstått som indikasjonar på kva barn meistrar og ikkje av skriftspråket (sjå t.d. Hofslundsengen, 2017).

Dette er ikkje ein studie av utdanningstekstar, men av kvardagslivets. Den etnografisk orienterte New literacy studies-tradisjonen (NLS) er oppteken av folk sin bruk av tekstar (jf. Barton \& Hamilton, 1998; Karlsson, 2006), og er eit utgangspunkt også i denne studien, der eg har fylgt fem femåringar heime og i barnehagen for å studera literacyhendingar og -praksisar, dokumentert gjennom feltnotat og innsamling av tekstar. Tradisjonen har imidlertid vore kritisert for å ha lite å bidra med når det gjeld meir heilskaplege forståingar av barn sine tekstar og tekstpraksisar på grunn av den insisterande lokale og partikulære tilnærminga (Schultz et al., 2016), og for å ha lite å seia om sjølve tekstane (Karlsson, 2006, s. 28). I denne studien vert NLS lagt til grunn metodisk for datainnsamlinga, dermed legg det også nokre premissar for forståinga av tekstane. Dette vert supplert med tekstteoretiske perspektiv for å analysera tekstar.

Den retoriske tradisjonen er oppteken av korleis me brukar tekstar og andre ytringar til å handla sosialt (jf. Miller, 1984). Det gjer han til eit godt utgangspunkt for å studera born sine tekstar i bruk. Samstundes har fleire tradisjonelle tekstanalytiske tilnærmingar, inkludert retorikken, vorte kritisert for å ha eit «motsvarande» problem med heilskapsforståing til dei etnografiske tilnærmingane - retorikken m.fl. kan kritiserast for å ikkje ta tilstrekkeleg høgd for tekstens plassering i konteksten, men føresetja at teksten representerer den sentrale handlinga (Karlsson, 2010). Difor vil 
ei retorisk tilnærming verta supplert med såkalla aktør-nettverk-teori (ANT), som fokuserer på nettopp samarbeidet mellom ulike einingar, som til dømes tekstar og personar, men utan å gje nokon ein førehandsprivilegert posisjon. Retorikk og ANT ser eg meir som teoretiske perspektiv som kan bidra til forståing av tekstar enn som metodologiske prinsipp. Ein premiss for studien er eit multimodalt tekstomgrep, der skriftspråk ikkje vert sett som eit naudsynt kriterium (sjå s. 6 ff).

Føremålet med denne artikkelen er å bidra til ei betre forståing av dei tekstlege ytringane til born under skulealder, gjennom å kombinera eit etnografisk basert bruksperspektiv med eit kontekstmedvite tekstperspektiv. Dette kan formulerast i problemstillinga: Kva brukar born som enno ikkje har fått formell lese- og skriveopplaring, eigeninitierte og -produserte tekstar til, praktisk og kommunikativt? Dette vert operasjonalisert til eit treledda analysespørsmål, som vert stilt til alle fem tekstane: a) Kva slags meiningsfulle samanhengar inngår teksten i? b) Kva slags plass har teksten i desse? c) Kva seier teksten? Desse spørsmåla vert både brukte i analysen av kvar enkelt tekst, og til diskusjonen av den overordna problemstillinga.

\section{Forsking på tekstbruk hjå born under skulealder}

Det er vanleg i skriftlege samfunn at fem-seksåringar utforskar skriftspråket før dei byrjar på skulen (Barton, 1994/2007; Heath, 1983; Hofslundsengen, Gustafsson \& Hagtvet, 2019; Kress, 1997; Treiman \& Broderick, 1998). Men kva brukar femåringar og andre born under skulealder tekstar til? New literacy studies-tradisjonen tek nettopp utgangspunkt $\mathrm{i}$ "people's uses of literacy, not [...] their formal learning of literacy» (Barton, 1994/2007, s. 34), også når det gjeld born. Frå denne tradisjonen kjem den sentrale nemninga literacyhending, som også kan tena som ei innramming av femåringar sine episodar med tekstbruk: «any occasion in which a piece of writing is integral to the nature of the participants' interactions and their interpretive processes» (Heath, 1982, s. 93). David Barton skildrar born sin bruk av tekstar i heimen som i større og mindre grad styrt og initiert av vaksne, som i literacypraksisen høgtlesing på senga (1994/2007, s. 140-148). Dette gjeld også ofte tidleg skriving, der born t.d. skriv bokstaven eller namnet sitt på kort. Han nemner også andre døme på kva born brukar tekstar og skriving til (før dei har lært skriving gjennom formell instruksjon): å gje beskjedar, å laga artefaktar til leik. Han skriv at ofte er aktiviteten skrivinga inngår i, viktigare enn skrivinga/teksten sjølv (Barton, 1994/2007, s. 156). Gunther Kress, knytt til men ikkje direkte del av denne tradisjonen, skriv at born brukar tekstar til både representasjon og kommunikasjon, og viser døme på at ungar før skulealder skriv namnet sitt, lagar forteljingar, avis, artefaktar til leik (handleliste), menyar og bøker (1997, s. 63-76). Worthington og Oers viser korleis 3-4-åringar brukar tekstar og grafiske symbol eigeninitiert i rolleleik i barnehagen, i ei rad sjangrar knytte til leiken (2017).

I ein skandinavisk samanheng er det dei siste åra kome fleire studiar av korleis barn deltek i literacypraksisar i heim og barnehage. Fast finn at heime deltek barnehageborn 


\section{G. K. Fuuhl}

i literacyaktivitetane i familien, som kan vera knytte til t.d. forbruk, religion og populærkultur, media, morsmål (2007). Dette samsvarar med tidlegare studiar (jf. td. Purcell-Gates, 1996). Borna praktiserer lesing og skriving knytt til populærkultur og media, og deler engasjementet for populærkulturelle tekstar med andre born (Fast, 2007). Karrebæks studie av korleis fotballkort er det som gjev meining til bokstavlæring for ein seksåring, kan sjåast som eit konkret tilfelle av dette (2013). Marit Holm Hopperstad, Marit Semundseth og Rutt Trøite Lorentzen har sett på kva som gjev femåringar lyst til å skriva i barnehagen (2009). Det er eit spørsmål nært knytt til kva dei brukar tekstar til. Dei identifiserer fire «funksjonar» skrivinga har for dei femåringane som er studerte: å markera identitet, å utforska kvardagslege erfaringar, å skapa eit estetisk uttrykk og å vera i lag. Dei siste åra er digitale medium vorte ein del av også born under skulealder sin kvardag, og særleg nettbrett er utbreidd og populært. Å sjå på YouTube-klypp er spesielt populært mellom dei yngste (Letnes, Sando \& Hardersen, 2016, s. 39). Jæger og Hoel har undersøkt bruk gjennom å fylgja (kvart sitt) barn som lagar forteljande digitale tekstar med støtte frå ein vaksen (Hoel, 2018; Jæger, 2013).

Femåringar brukar altså tekstar til å delta i kvardagen i familien. Dei brukar tekstar reseptivt til underhaldning og fantasi/fiksjon, i form av både høgtlesing, tv og bruk av digitale medium, t.d sjå YouTube-klypp eller seriar på nettbrett. Når det gjeld den produktive bruken av tekstar, kompliserer det seg noko. Det er ikkje så lett å føra saman Bartons konkrete skildringar og Hopperstad, Semundseth og Lorentzens avleidde "funksjonar», men me kan rekna med at å skriva namnet eller bokstaven sin og «å markere identitet» handlar om noko av det same, og sannsynlegvis er sentralt $\mathrm{i}$ tidleg skriftbruk, sidan det vert funne fleire stader, også i andre typar studiar (Bloodgood, 1999; Kress, 1997; Treiman \& Broderick, 1998). Elles nemner Barton, Kress og Worthington og van Oers at ungar brukar tekstar i samband med leik, men dette finn me ikkje att hjå Hopperstad, Semundseth og Lorentzen, som har teke utgangspunkt i delvis organisert teikne- og skriveaktivitet i barnehagen. Kategorien deira «å skape et estetisk uttrykk» høver imidlertid godt på Hoel og Jæger sine studiar av born som lagar digitale bøker. Det kan altså sjå ut til at kva forskinga finn ut at born i femårsalderen brukar tekstar til, til ein viss grad handlar om kva slags situasjonar forskarane vel å sjå etter tekstbruk i.

\section{Forsking på tekstar av born under skulealder}

I ein god del studiar i tilknyting til New literacy studies-tradisjonen der ein også ser på tekstar, er sosialsemiotisk teori, og gierne multimodalitetsteori, utgangspunkt for tekstanalysane (sjå t.d. Gilje, 2010; Hopperstad, 2002; Karlsson, 2002; Kress, 1997; Michelsen, 2016; Worthington \& van Oers, 2017). Gunther Kress har utvikla multimodalitetsteori (Kress \& Van Leeuwen, 1996/2006) og studert born under skulealder (mest eigne born) sine tekstar. Han er oppteken av korleis barnet si interesse i det representerte styrer kva aspekt som vert representert og kva slags modalitetar som 
vert valde. Kress skildrar born sine ytringar som både representasjon og kommunikasjon, men tykkjest mest oppteken av representasjonsdimensjonen (Kress, 1997, s. 14). Hopperstad sine studiar av seks- og toåringar sine teikningar tek utgangspunkt i dette paradigmet (Hopperstad, 2002, 2013). Dei viser korleis modalitetane i ein tekst spelar saman, og spelar ulike roller. Studiane hennar viser fram kompetanse hjå ungane og kompleksitet i dei tekstlege produkta som kanskje vert oversett i barnehagekvardagen. Vekta på representasjon av eit innhald i desse studiane kan gjera at handlinga tekstane vert brukte til å utføra vert mindre i fokus.

I norsk samanheng har Rutt Trøite Lorentzen skrive om born sine tidlege tekstar, og vore ein eksponent for synet at det å ha nokon å skriva til er viktig for borns tidlege tekstskaping (Lorentzen, 1995, 2004). Fleire andre studiar legg vekt på dette trekket (Evensen, 2013; Matre, Sjøhelle \& Solheim, 2012). Materialet for desse nemnde studiane er tekstar av born som står forfattarane nær. Kanskje eit slikt utval legg til rette for å fanga opp ein bestemt type av born sine tekstar?

\section{Kva er ein tekst? Tekstomgrepet og teoriar om tekst og kontekst}

Skal ein studera borns tekstar, treng ein eit tekstomgrep som rommar dei. Er til dømes ein bokstav på eit duplohus ein tekst? Kjell Lars Berge, som har arbeidd mykje med tekstdefinisjonar ut frå ei erkjenningsinteresse som ligg nær dette prosjektet, legg mellom anna vekt på at tekstar må ha ytre grenser og ein indre struktur, altså at me som lesarar forstår kvar han startar og sluttar (Asdal et al., 2008, s. 44; Berge, 2001, s. 62,2002 , s. 236). Berge skriv vidare at tekstar kan vera medierte ved hjelp av ulike modalitetar og at dei har, som alle ytringar, intensjonalitet. Berge legg likevel mest vekt på at tekstar må forståast og aksepterast av deltakarane, dei må fylgja konvensjonaliserte tekstnormer for å vera tekstar. Vidare kan tekstar typifiserast i sjangrar (sjå Asdal et al., 2008; Berge, 2001, 2002). Dette stør seg mellom anna på Carolyn Millers merknad om at sjangrar består av «komplette tekstar», som er omgjevne av eit relativt fullstendig skifte i retorisk situasjon (Miller, 1984).

Er så ein bokstav på eit duplohus ein tekst? Svaret må vera at det kjem an på. Eit namneskilt fyller krava frå avsnittet over - det kan typifiserast og kallast ved eit sjangernamn. Eit namneskilt har ei meining me forstår, og det har ei ytre avsluttaheit og ein indre struktur. Om me forstår at ein bestemt bokstav på eit bestemt duplohus er meint å vera eit namneskilt, kan me sjå at han har ganske mange teksteigenskapar, nok til at me i stor grad kan behandla han som ein tekst. Vert me tvungne til å klassifisera, kan det henda me vil kalla han ein prototekst, fordi han har mange teksteigenskapar, men ikkje nødvendigvis stettar alle krav. Mange femåringstekstar vil sannsynlegvis befinna seg i eit slikt landskap.

Dette tekstomgrepet let definisjonen byggja på korleis me handlar i verda med tekstar, og er såleis knytt til den pragmatiske synsmåten som ligg til grunn for retorikken. Med retorisitet meiner eg her det same som Lloyd Bitzer: at tekstane er ytringar som svarer på retoriske behov (exigences), som manifesterer seg i situasjonar som inviterer 


\section{G. K. Fuuhl}

til eit svar, det som vert kalla retoriske situasjonar (Bitzer, 1968). Desse ytringane eller tekstane kan ifylgje Carolyn R. Miller sjangersorterast på bakgrunn av kva retoriske situasjonar dei svarer på, og kva handlingar dei utfører som svar, altså er sjangrar typifiserte retoriske handlingar basert på tilbakevendande situasjonar (Miller, 1984, s. 159). Eit viktig poeng i høve tekstane i denne studien, er at Miller meiner sjanger er ein av klassifiseringane av tekstar me gjer i livet ut frå praksis. Sjangeromgrepet hennar gjeld altså kvardagslivets tekstar og sjangerfestingar (Miller, 1984, s. 155). Ein del av analysen av tekstane vil såleis handla om sjangerfesting.

Trass i det tette sambandet mellom tekst og verd i retorikken, hevdar Anna-Malin Karlsson at retorikk deler ein «tekstbias» med fleire andre tekstteoretiske og -analytiske retningar som studerer tekstar i kontekst, mellom anna kritisk diskursanalyse (2010). Ho hevdar at retorikken fyrst og fremst er interessert i tekstar som er sentrale i den praksisen dei er ein del av (2010, s. 165). Når ein skal undersøkja tekstars roller i ulike praksisar, må ein også vera open for tilfelle der teksten ikkje er så sentral. På den bakgrunnen stiller ho spørsmålet om korleis ein skal forstå og kva analytiske reiskapar ein skal bruka for å få has på rolla til slike tekstar - altså for å kunna skildra tekstar si rolle i ulike samanhengar meir føresetnadslaust (Karlsson, 2010, s. 164). Karlsson peikar på omgrep frå såkalla aktør-nettverk-teori (også kalla ANT. Sjå Latour, 2005) som fruktbare for å forstå tekstar si rolle i ulike samanhengar. Schultz, Hull og Higgs skildrar også aktør-nettverk-teori som ei produktiv tilnærming til studiar av fritidsskriving (2016). Eit trekk ved ANT som vil verta brukt her, er at også objekt (som t.d. tekstar) kan ha aktørstatus (Latour, 2008, s. 74). Situasjonar som synleggjer kva ulike objekt er og gjer, og korleis dei kan vera mediatorar (noko som bidreg til mellombels stabilisering), er situasjonar der objekta vert fråtekne si vanlege usynlegheit, til dømes når dei vert laga og når nokon som manglar ferdigheiter interagerer med dei (Latour, 2008, s. 102-104). Karlsson vurderer desse to eigenskapane ved tekstar som aktørar som særleg analytisk fruktbare: mellombels, tilfeldig stabilisering og flyttbarheit (Karlsson, 2010, s. 172). Desse vert brukte i analysen.

\section{Om materiale og metode}

Tekstane som vert analyserte i denne artikkelen er ein del av eit materiale samla inn i samband med studien Skriftkvardagen til femåringane, som vart gjennomført i 2018-19. Fyrst vert materiale og metode frå den tilgrunnliggiande studien presentert, deretter vert metodiske spørsmål som gjeld denne artikkelen spesifikt tekne opp.

Føremålet med studien var å få fram djupnekunnskap om korleis skriftkvardagen til born under skulealder i eit nynorskområde arta seg, heime og i barnehagen. ${ }^{1}$ Det finst få norske studiar av tilsvarande type. Eit uutforska landskap ligg til rette for ei etnografisk tilnærming, som handlar om å vera nær det som skjer og i størst mogleg grad prøva å sjå og forstå det deltakarane ser og forstår (Heath, Street \& Mills,

\footnotetext{
${ }^{1}$ Nynorskperspektiv på skriftkvardagen til desse borna vert undersøkt i Juuhl, 2020.
} 
2008, sjå t.d. s. 38-42). New literacy studies er nettopp ein forskingstradisjon som driv detaljerte studiar av kva folk gjer med skrift og tekstar, og har utvikla termane literacyhending (Heath, 1982) og literacypraksis (Street, 1984) som ordnande reiskapar for å skildra dette.

I denne studien er det altså fem femåringar frå same avdeling i same barnehage, siste året $\mathrm{i}$ barnehagen, som står $\mathrm{i}$ sentrum. Utvalet var gjort med utgangspunkt $\mathrm{i}$ eit ynske om å studera literacyhendingar slik dei utfalda seg på ein lokalitet med bestemte kjenneteikn. Med ein lokalitet som utgangspunkt ville ikkje på tvers-samanlikning vera mogleg, men materialet frå dei ulike situasjonane (barnehage og heime) og dei ulike borna ville kunna kasta lys over kvarandre, og gje ein indre samanheng. På denne måten kan utvalet skildrast som ein case, altså ei undersøking som brukar ei allereie eksisterande grense for kva og kven undersøkinga inkluderer og ekskluderer (Tjora, 2017, s. 41).

Barnehagen hadde ei avdeling berre for ungar som gjekk siste året i barnehagen. Pedagogisk leiar var viljug til å delta i prosjektet. Dermed er også strukturen til barnehagen styrande for at det vart berre femåringar som vart med i studien. Dei fem borna som deltok, vart valde ut fordi det var deira foreldre som melde seg. Dette utvalet er ikkje representativt for borna på avdelinga eller for born generelt.

Prosjektet vart presentert på foreldremøtet, og foreldra fekk med informasjonsskriv og invitasjon til å delta, der føremålet med prosjektet og kva deltaking innebar for born og foreldre, vart presentert. Foreldra som ynskte å delta, leverte inn svarslipp med kontaktinformasjon. Fyrste gong eg besøkte kvar familie, fortalde eg barnet og den/dei vaksne om kvifor eg var der. Nokre av borna var entusiastiske ved fyrste besøk, medan andre var meir tilbakehaldne. Etter kvart oppfatta eg at besøka vart opplevd som meiningsfulle av alle borna, og at det å ha ein interessert vaksen på besøk som ville vera med å spela spel, sjå på russekortsamlinga eller tv, eller liknande, vart opplevd som greitt. Eg la også opp til at foreldra var til stades medan eg var på besøk, og vende meg i starten mest til foreldra og etter kvart som borna vart trygge, meir direkte til borna. Prosjektet er meldt inn til og tilrådd av NSD.

Eg har besøkt kvart og eitt av borna fem gonger heime på ettermiddagen, og vore i barnehagen åtte føremiddagar. Metoden for datainnsamling har vore delvis deltakande observasjon. Dokumentasjonen har skjedd med penn og papir gjennom feltnotat, og gjennom innsamling og foto av tekstar som borna har laga eller interagert med på andre vis. Avidentifisert materiale har vore lagra på pc med internettilgang, og kodenøkkel i ein låst skuff. Feltnotata har vore fokuserte for å fanga literacyhendingar som barnet har delteke i, men har ikkje vore strukturerte utover det. Spørsmål, svar og brokkar av samtale knytt til literacyhendingar har også vore nedteikna.

Det vert ein uvanleg situasjon for ein familie å ha ein framand person med notatblokk i sofaen, og det påverkar nok interaksjonen i familien - samstundes er ikkjeforstyrrande observasjon i prinsippet umogleg (Karlsson, 2006, s. 151). Dei potensielle problema med ein slik uvanleg situasjon, er at ein ikkje får sjå den kvardagen ein er ute etter å studera fordi ein lagar ein uvanleg situasjon, og at ein gjer deltakarane 


\section{G. K. Fuuhl}

ukomfortable. Når det gjeld det fyrste problemet: Trass i at situasjonen vert noko kunstig, kan ein anta at det ungar viste, spontant, då eg var der, av literacyaktivitetar, og dei tekstane som var i heimen, utgjorde ein del av eit tilgrunnliggjande literacyrepertoar som barnet og familien hadde - og at det eg såg difor var ting som allereie fanst i skriftkvardagen, sjølv om det at eg var til stades, kan ha bidrege til hyppigare brettspeling og høgtlesing enn vanleg. Når det gjeld problemet med utryggleik, vart det mellom anna forsøkt handtert ved at ved at eg som forskar var der fem ettermiddagar, og også besøkte barnehagen i same tidsrom, slik at borna etter kvart kjende meg. Eg let også ungane sjå i notatblokka mi, og las gjerne opp når dei spurde kva eg skreiv der, og dei fekk også teikna eller skriva i blokka mi sjølve om dei ville. Eg tok også med feltnotata tilbake til foreldra til gjennomsyn ved neste besøk.

I barnehagen er det truleg ein mindre unaturleg situasjon å ha personar som observerer på besøk. Det er ulike faggrupper inne og observerer, og det er ofte studentar i praksis.

\section{Tabell over innsamla materiale}

\begin{tabular}{|c|c|c|c|c|}
\hline Barn & Tidsrom & $\begin{array}{l}\text { Feltnotat } \\
\text { heime }\end{array}$ & Materiale & Anna info \\
\hline Simon & $\begin{array}{l}\text { Nov. } 2018- \\
\text { jan. } 2019\end{array}$ & $\begin{array}{l}5 \text { besøk på ca. } \\
1 \text { time }\end{array}$ & $\begin{array}{l}5 \text { feltnotat, } 1 \text { fotografert } \\
\text { tekst av barnet }\end{array}$ & $\begin{array}{l}\text { Bur saman med mor og far, to } \\
\text { eldre systrer }\end{array}$ \\
\hline Maria & $\begin{array}{l}\text { Nov } 2018- \\
\text { mai } 2019\end{array}$ & $\begin{array}{l}5 \text { besøk på ca. } \\
1 \text { time }\end{array}$ & $\begin{array}{l}5 \text { feltnotat, } 3 \text { fotograferte } \\
\text { tekstar av barnet }\end{array}$ & $\begin{array}{l}\text { Bur saman med mor og far, ein } \\
\text { eldre bror og ei eldre syster }\end{array}$ \\
\hline Maja & $\begin{array}{l}\text { Des. } 2018- \\
\text { feb. } 2019\end{array}$ & $\begin{array}{l}5 \text { besøk på ca. } \\
1 \text { time }\end{array}$ & $\begin{array}{l}5 \text { feltnotat, } 6 \text { fotograferte } \\
\text { tekstar av barnet }\end{array}$ & $\begin{array}{l}\text { Bur saman med mor og far, to } \\
\text { eldre brør }\end{array}$ \\
\hline Christina & $\begin{array}{l}\text { Nov. } 2018- \\
\text { mar. } 2019\end{array}$ & $\begin{array}{l}5 \text { besøk på ca. } \\
1 \text { time }\end{array}$ & $\begin{array}{l}5 \text { feltnotat, } 4 \text { fotograferte } \\
\text { tekstar av barnet }\end{array}$ & $\begin{array}{l}\text { Bur saman med mor og far, ei } \\
\text { veslesyster }\end{array}$ \\
\hline Peter & $\begin{array}{l}\text { Mai 2019- } \\
\text { jun. } 2019\end{array}$ & $\begin{array}{l}5 \text { besøk på } \\
1-2 \text { timar }\end{array}$ & $\begin{array}{l}5 \text { feltnotat, } 3 \text { fotograferte } \\
\text { tekstar av barnet }\end{array}$ & $\begin{array}{l}\text { Bur saman med mor og far og } \\
\text { ei storesyster. Tospråkleg }\end{array}$ \\
\hline Bhg (Peter) & $\begin{array}{l}\text { Mai } 2018- \\
\text { jun. } 2018\end{array}$ & 2 føremiddagar & $\begin{array}{l}2 \text { feltnotat, foto av } \\
\text { omgivnader }\end{array}$ & \\
\hline Bhg (dei andre) & $\begin{array}{l}\text { Nov. } 2018- \\
\text { feb. } 2019\end{array}$ & $\begin{array}{l}6 \text { føremiddagar } \\
\text { (ca. 9-1130) }\end{array}$ & $\begin{array}{l}6 \text { feltnotat, foto av } \\
\text { omgivnader }\end{array}$ & \\
\hline
\end{tabular}

I denne artikkelen ser eg nærare på tekstar som desse borna har laga på eige initiativ. Det varierte kor mykje borna skreiv. Eg har valt ein tekst frå kvart born, for å få like mange frå kvar, for å lata kvart barn få like stor plass som tekstprodusent, trass $\mathrm{i}$ at formelle skriveferdigheiter og tekstproduksion varierte, og samtidig ei handterbar tekstmengd å analysera. Elles var utvalskriteriet at teksten fylte tekstkriteriet «avsluttaheit», vart brukt og/eller referert til av barnet medan eg var til stades, altså at han opptredde $\mathrm{i}$ ein kommunikativ samanheng og dermed vart tileigna ein verdi av barnet. Informasjon frå feltnotata om bruk av tekstane er supplerande materiale. Ein del av tekstbitane som ikkje vart valde ut for analyse, var i mindre grad heile tekstar, som 
lister over ord, enkeltord, ei delvis utfylt yatzyblokk, kladd til rekning, medan nokre i større grad var heile tekstar, som eit kort til meg, teikningar, tekst i vindaugskarmen. Fire av dei fem tekstane er produserte i heimen, og ein frå barnehagen, men bringa inn i heimen av barnet. Dette fortel truleg noko om både observasjonssituasjonen og tilhøvet mellomheim og barnehage: I barnehagen var dei fleste literacyaktivitetar vaksenstyrte, og det var mindre rom til eigeninitiert tekstproduskjon hjå enkeltbarn. I barnehagen var eg også som observatør mindre tett på enelktborn, for ikkje å gripa inn i det som føregjekk. Dermed er nok heimen både ein stad som inviterer meir til eigeninitiert tekstproduksjon, og til å visa fram kva ein har laga til ein forskar. Dei utvalde tekstane vert presenterte i samband med analysane.

\section{Analysar}

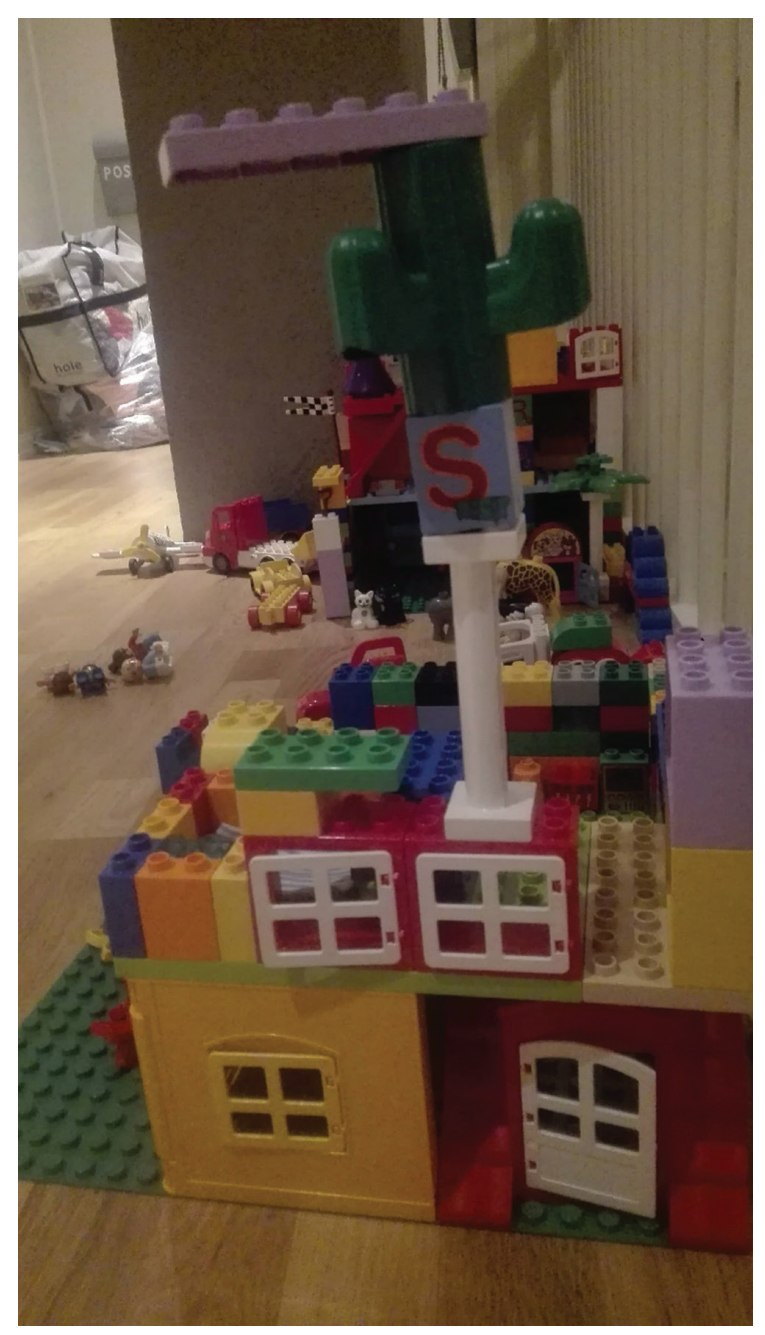

Simon: namneskilt og husnummer 


\section{G. K. Fuuhl}

Teksten til Simon var ikkje laga under eitt av mine besøk, men eg oppdaga han då eg var på besøk, og fatta interesse fordi han vart referert til av Simon, under to ulike besøk. Det er ein S på eit duplohus som han har bygd. Slik kommenterer Simon teksten:

Så sit me i loftsstova og snakkar litt om bøker og litt om duplo. Simon viser meg ting med duplohuset sitt - at han har lys han kan slå på, vaksendør og barnedør, og postkasse, og eit tårn med eit lite skilt det står S på, "slik at dei kan sjå at her bur eg». (Feltnotat 6.11.18)

Eg spør Simon igjen om eg kan få sjå duplohuset hans, og ta bilete av det. Ja, det får eg. Me går opp og ser på. Simon fortel meg litt om huset, der er ein bil og der er nokre mus. Han peikar på tårnet/klossen der det står S, og seier at det er husnummeret. (Feltnotat 13.11.18)

Det Simon sjølv seier når han referer til S-en, peikar mot dei symbolske handlingane som ligg i sjangrane dørskilt og husnummer, nemleg å formidla kven som bur i eit hus og «identiteten» til eit hus. Ut frå det han seier, går det også fram at dette teiknet er noko anna enn huset det står på - det er ein tekst som seier noko om huset.

Eit husnummer på eit duplohus kan vera ein tekst som ikkje er sentral i praksisen han er ein del av, jf. Karlsson (2010, s. 164). I mange tilfelle vil leiken til Simon og storesystrene med duplohuset (og systrene sine duplohus) og duplofolk vera det sentrale, ikkje namneskilt eller husnummer. Likevel bidreg namneskiltet/husnummeret i samanhengen som leiken er, fordi det kan sjåast som ein (eller to) av fleire aktørar som bidreg til å stabilisera duplohuset som hus, ved at dei utgjer kjenneteikn på hus, i lag med andre aktørar som også gjer eit duplohus til eit hus, som lys som kan slåast av og på, ulike dører og duplofolk som bur i huset.

Sjølv om S-en på duplohuset ikkje alltid uttrykkjer den sentrale handlinga i situasjonen, kan retorisk sjangerteori brukast til å seia oss noko om kva som er meininga med S-en, altså kva slags ytring han skal forståast som: Både namneskilt (dørskilt som ein undertype) og husnummer er komplette tekstar, og typar av tekstar som me kjenner att, og som har ein attkjenneleg funksjon. Namneskilt seier kven som bur her, kven som eig noko eller kven nokon er. Det tileignar namn til noko eller nokon. Husnummer har ein liknande, men ikkje heilt identisk funksjon. Så med å setja S-en på huset, har Simon (anten åleine eller i lag med systrene) sett namnet sitt på huset sitt, «slik at dei kan sjå at her bur eg», som han seier.

Mange studiar viser også at noko av det fyrste born lærer å lesa og skriva, er bokstaven sin, og at «bokstaven min» er eit meiningsfullt stykke skriftspråk for born før dei meistrar lesing og skriving meir komplett (Treiman \& Broderick, 1998; Welsch, Sullivan \& Justice, 2003). Når Simon refererer til denne S-en som to ulike typar namngjeving: namneskilt og husnummer, kan me forstå det som ei utforsking av, eller arbeid innan sjangerklyngja namngjeving.

Dersom Simon på dette tidspunktet hadde hatt full kontroll over skriftspråket, hadde det tvetydige rommet der S-en på huset både kunne vera namneskilt og husnummer, vore lukka. Det er eit døme som viser at erobring av sjangrar og erobring av skriftspråk heng saman, ikkje nødvendigvis slik at det eine kjem før det andre, men 
vikla saman på ulike måtar. At S-en til Simon varierer mellom å vera namneskilt og husnummer, kan også visa oss at stabilisering av tyding er ein prosess som heile tida må haldast ved like, og der tekstar og menneske må samarbeida (sjå Latour, 2008, s. 99-101).

Oppsummert kan me seia at me må forstå denne teksten på ein måte som ytring $\mathrm{i}$ det han vert laga, og på andre måtar som ein del av huset, av leiken, eller av samtalar om huset. Samstundes er det gjennom ombruken me får tilgang til kunnskap om meininga i å produsera denne teksten.

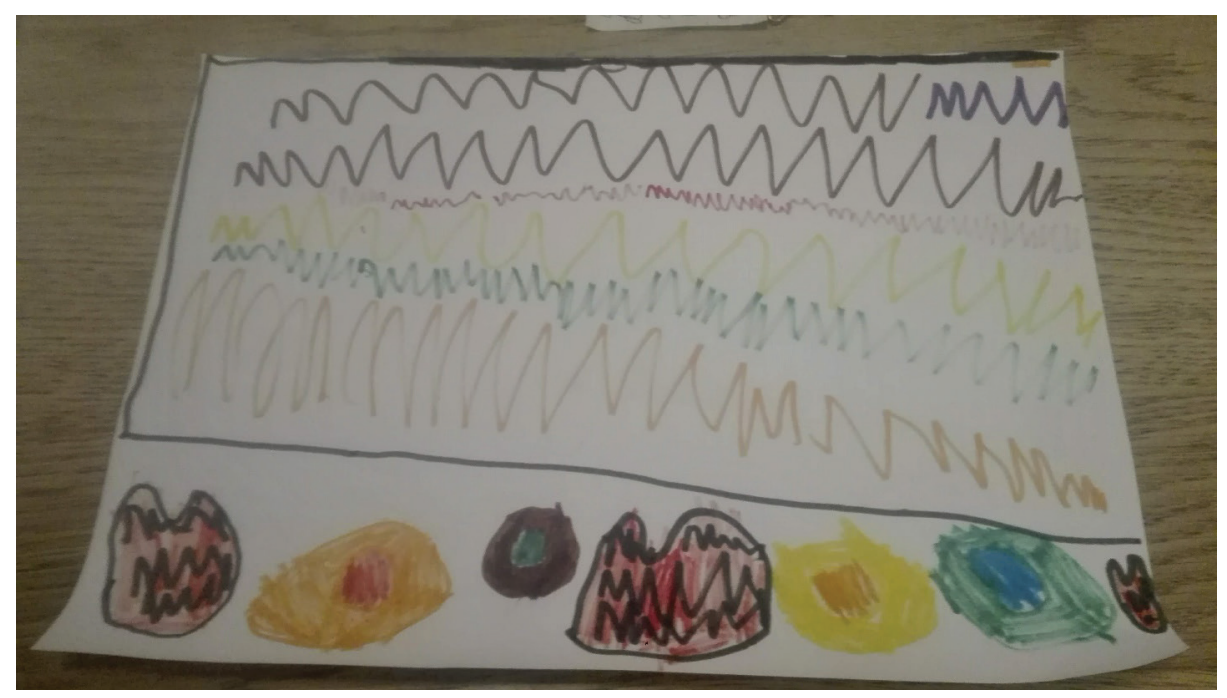

Maria: hjartemaskin

Teksten til Maria er eit fargesprakande, multimodalt samspel, men for å finna ut kva han tyder, er me som er utanforståande avhengige av informasjon frå konteksten. Utdrag frå feltnotat:

Maria finn noko ho hadde teikna. Eg spør kva det er. Ho fortel at det er ei hjartemaskin. Ei stor og ei lita. Maskina tel hjartedunk og så viser det på skjermen. Ho likar å leika dokter og då er hjartemaskina ein del av det. Maria fortel at ho leikte dokter i barnehagen i dag med veninna og kompisen sin. Dei var kattar, ho var lege, og då brukte ho hjartemaskina. Maria viser fram to hjartemaskiner ho har teikna.

(Feltnotat 21.11.18)

Maria fortel at dette er ei hjartemaskin, og korleis ho har brukt henne. Når me veit at det er ei hjartemaskin (kardiograf), forstår me at "skriblinga» representerer hjarteslaga. På nedste rada er det sirklar med sirklar inni, som truleg representerer knottar på apparatet, og noko som kan vera symbolske hjarte med hjarteaktivitet. Det er altså ei avbilding av ein kardiograf, laga for å representera ein kardiograf $i$ leiken.

Hopperstad skildrar i sin studie av småborn som målar tekst, borns tekstar som multimodale på den måten at dei består både av det som vert måla og den 


\section{G. K. Fuuhl}

medfylgjande snakkinga (2013). Når det gjeld denne teksten, var eg som utanforståande avhengig av ei forklaring for å forstå kva som vart representert, men med ein gong eg fekk den, såg eg det. Denne teksten av ein femåring er altså ikkje i same grad som småborns typiske tekstproduksjon avhengig av den medfylgjande snakkinga.

Skal me ta utgangspunkt i forklaringa til Maria, ser me at denne teksten inngjekk i den meiningsfulle samanhengen dokterleik. I denne leiken er hjartemaskina ein betydningsfull komponent, men ikkje nødvendigvis den viktigaste. Hjartemaskina var ein aktør som bidrog til å stabilisera den fiktive konteksten «hjå dokteren", som var nødvendig for leiken. Andre aktørar som bidrog var Maria som dokter og venene hennar i roller som kattepasientar.

Det går også fram at Maria har teke med seg hjartemaskina frå barnehagen. Det understrekar teksten si flyttbarheit og evne til å vandra mellom kontekstar. Når denne teksten kan takast med heim, kan han brukast i dokterleik begge stadene. I feltnotatet inngår han i handlinga å visa fram og fortelja om noko til nokon. På den måten viser han tekstar si evne til å halda på tyding frå ein kontekst inn i ein annan kontekst: stabilisering og flyttbarheit.

Har det retoriske sjangeromgrepet noko å seia om denne teksten? Han svarer på eit retorisk behov (exigence): behovet for ei hjartemaskin i dokterleiken. Det kan vera råd å sjå på det å laga liksom-artefaktar til leiken med papir og blyant som ei typifisert handling som denne teksten er eit tilfelle av. Miller skriv at tekstane som utgjer ein sjanger også bør ha ein viss innhaldsmessig og formmessig likskap (1984, s. 163). Slike artefaktar til leiken er nettopp prega av at dei er ulike - dei visuelle og tekststrukturelle eigenskapane til slike tekstar er knytt til den aktuelle leiken dei skal vera artefakt $i$, ikkje til den generelle retoriske situasjonen behovet for ein artefakt til leiken.

Me kan kalla det ein tekst som har eit hybridtilhøve til sjangrane, i det at han både dreg vekslar på exigensar og tekststrukturelle kjenneteikn frå den «vaksne og ikkjefiktive sjangeren» kardiogram og svarer på det barneopplevde behovet for ein liksom-artefakt, ei hjartemaskin i dokterleiken.

Den andre gongen eg er på besøk hjå Maja, finn eg desse lappane som ligg på eit lite bord. Lappane vert liggjande på det vesle bordet gjennom alle gongene eg er på besøk. Maja har skrive ulike ting på dei, m.a.:

LARMO

LARMONI

[del av namnet sitt]

SO IS SO IS

SO IS EMMA

MAJA (hjarte stjerne hjarte stjerne)

Når eg spør henne om lappane, seier ho om den eine:

der står det i alle fall Solis. Ho seier at ho elskar det. Den finst ikkje i verda, men den ser ut som ei sol og er laga av appelsin og sitron og litt godteri og litt brus [...] Maja seier om lappane: "eg tok berre sånn bla bla bla» medan ho viser med handa at ho skriv. (Feltnotat 21.01.19) 


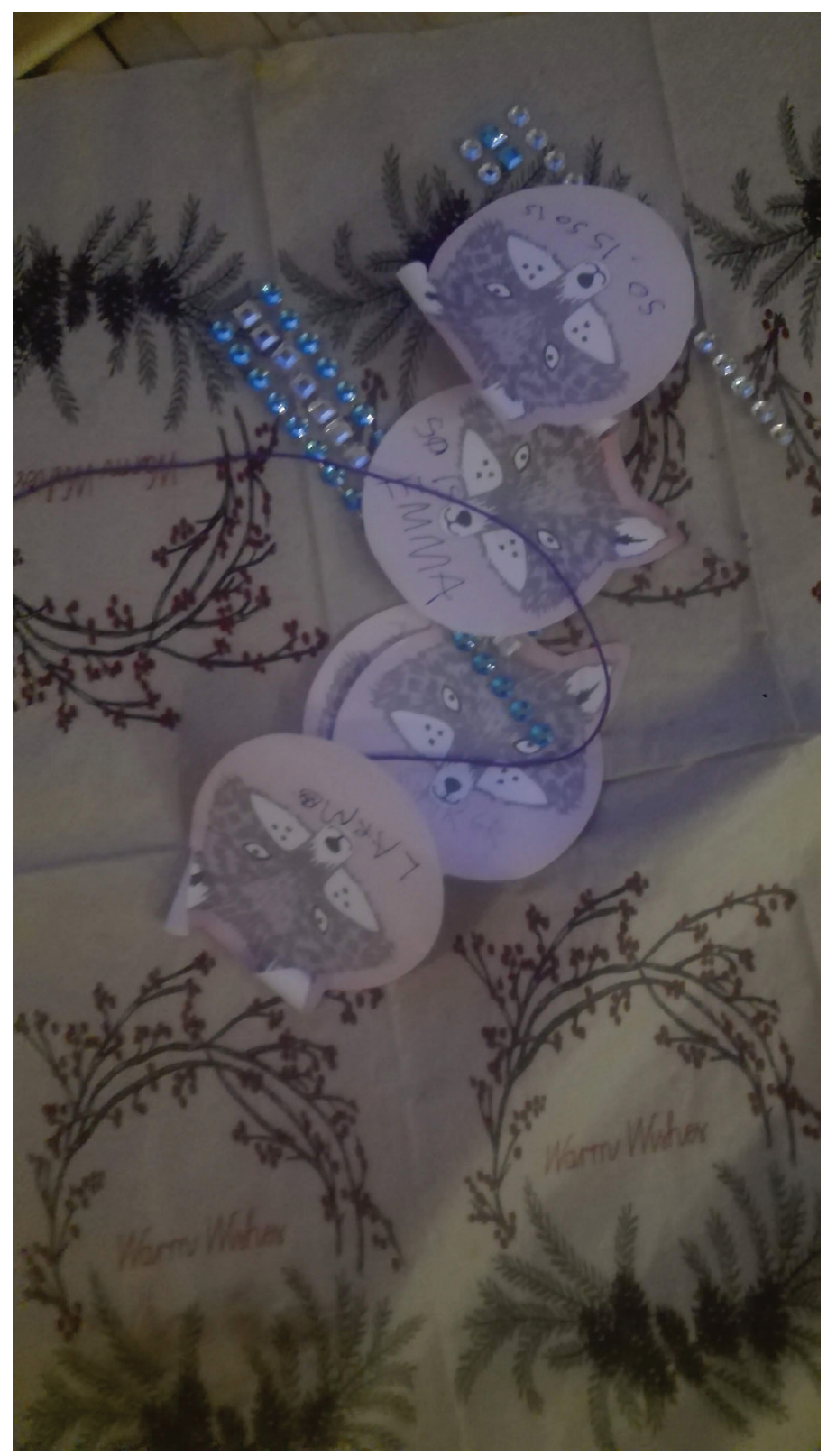

Maja: Solis

Maja sjølv framhevar lappen der det står SO IS SO IS gjennom å kommentera han og lesa kva som står. Difor tek me utgangspunkt i den. Lappen må likevel sjåast $\mathrm{i}$ samband med den tilbakevendande lappeskrivinga til Maja. Ein annan gong eg er på besøk, har ho skribla på gule lappar og hengt opp på veggen, og andre gonger får eg i oppdrag å skriva på gule lappar medan Maja dikterer. Å skriva lappar, utforska 


\section{G. K. Fuuhl}

skriftspråket gjennom å skriva, skribla, diktera og hengja opp lappar - kan altså sjåast som ein del av ei utforsking av skrivekunsten som Maja held på med jamleg i denne perioden. Om me ser denne lappen i samanheng med lappane han ligg på bordet saman med, der ho har skrive både heile ord og delar av ord, nye ord og ord som finst, kan me sjå han som ei handling i dette utforskingsarbeidet - kanskje om kva skrift kan giera?

Det Maja gjer i denne samanhengen, er imidlertid å lesa lappen og «utleggja» meininga $\mathrm{i}$ han. Me veit ikkje om dette var meininga Maja la i lappen då ho skreiv so is so is eller om dette fyrst og fremst er ei meining som vert skapt gjennom lesinga det syner kor ustabil den mellombels stabiliserte tydinga teksten er, og kor avhengig stabiliseringa er av samarbeid mellom tekst og menneske. Bokstavane som står på lappen bidreg til å stabilisera tydinga (dei utgjer fire av fem bokstavar i SOLIS), men gjer ikkje heile jobben åleine.

Når Maja les opp teksten og forklarer kva det tyder, hevdar ho makta til den som kan lesa og veit kva som står. For det fyrste les ho og bestemmer at det som står er Solis. For det andre legg ho ut kva Solis er. Eg forstår det som at med det tek ho i bruk, eller imiterer, sjangeren utlegning. Ved å finna opp sin eigen is med namn, deltek Maja også i sjangeren namngjeving.

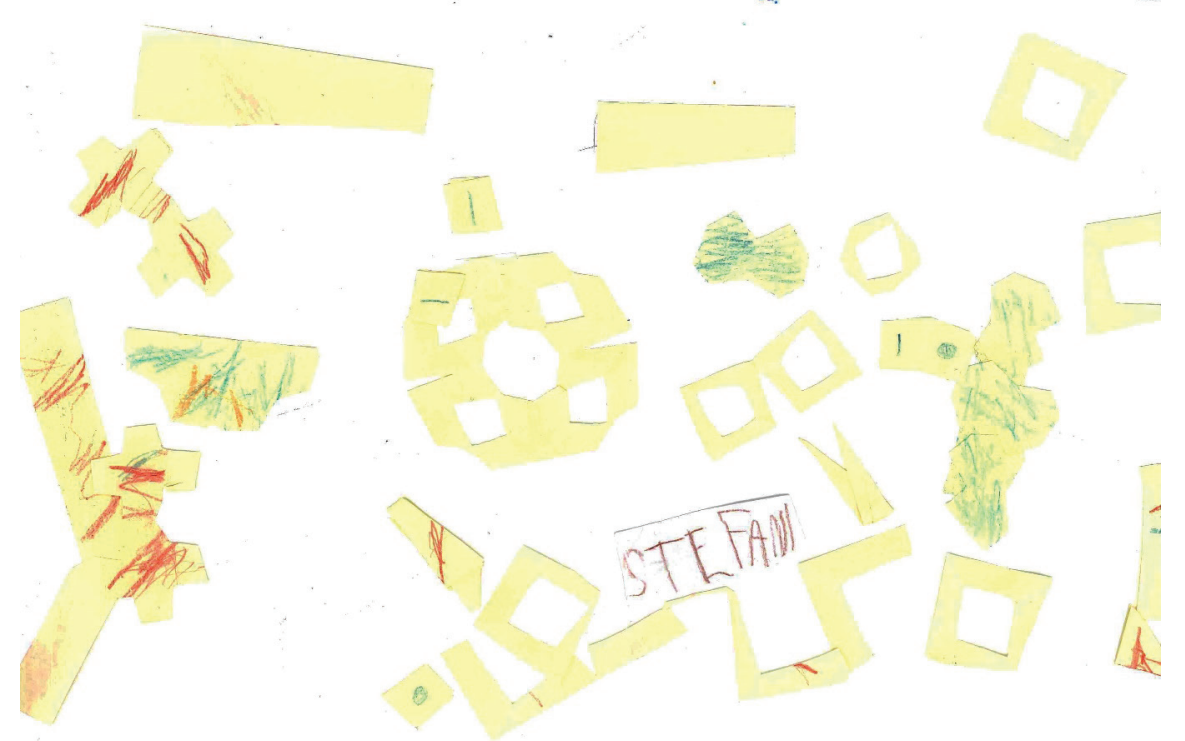

Christina: Stefani

Den teksten til Christina eg har valt ut, er lappen som det står STEFANI på. Stefani er namnet til ei av dokkene hennar. Christina og veslesystra har ein fast leik der 
Christina har skrive namn på dei som er med (inkludert dokkene deira) på lappar, og så skal ein trekkja lappar, og så er det den som har namnet sitt på lappen sin tur. Veslesystra trekkjer for dokkene. Når eg er på besøk, inngår lappen med namn på i ein haug av lappar som Christina og veslesystra lagar til meg, utan skrift, men der dei klypper og limer postitlappa så dei vert ting som bartar, briller og legoklossar.

Frå feltnotat:

Cristina skriv lappar og klypper, medan me sit i sofaen og tv er på. [...] Cristina klypper, S fargelegg. Eg får også ein lapp som er laga før som det står STEFANI på (det er namnet til ei av dokkene), eg får alle lappane. Cristina lagar lappar, seier: Dette er lego. Det er sånn du kan ha oppå lego. Cristina seier: Alle lappane lagar vi til deg. (Feltnotat 17.01.19)

Christina omtalar lappane samla som lappar, både den med og dei utan skrift, og grupperer dei slik som det same.

Namnelappar er ein variant av namngjevingssjangeren som er gjort greie for før. Men ser me på korleis lappen som det står Stefani på er i bruk i leiken og i gåveproduksjonen til meg, ser me at teksten inntek meir perifere roller, og ikkje nødvendigvis er sentral i den retoriske handlinga som vert utført. Leiken er ein type rolleleik (der dokkene får roller) som handlar om leiken. Det som står i sentrum er å trekkja lappar, at Christina les dei og seier kven sin tur det er. På den måten er lappane nødvendige aktørar i leiken, dei er eit nødvendig grunnlag for handlinga å tildela tur, men dei utgjer ikkje denne handlinga, for utpeikinga/utveljingsshandlinga er også avhengig av det overordna regelsettet for leiken, Christina si lesekunne og at veslesyster har trekt. I gåveproduksjonen til forskargjesten er Stefani-lappen ein endå meir perifer aktør. Der er han berre ein av mange lappar som vert samla og gjeve bort.

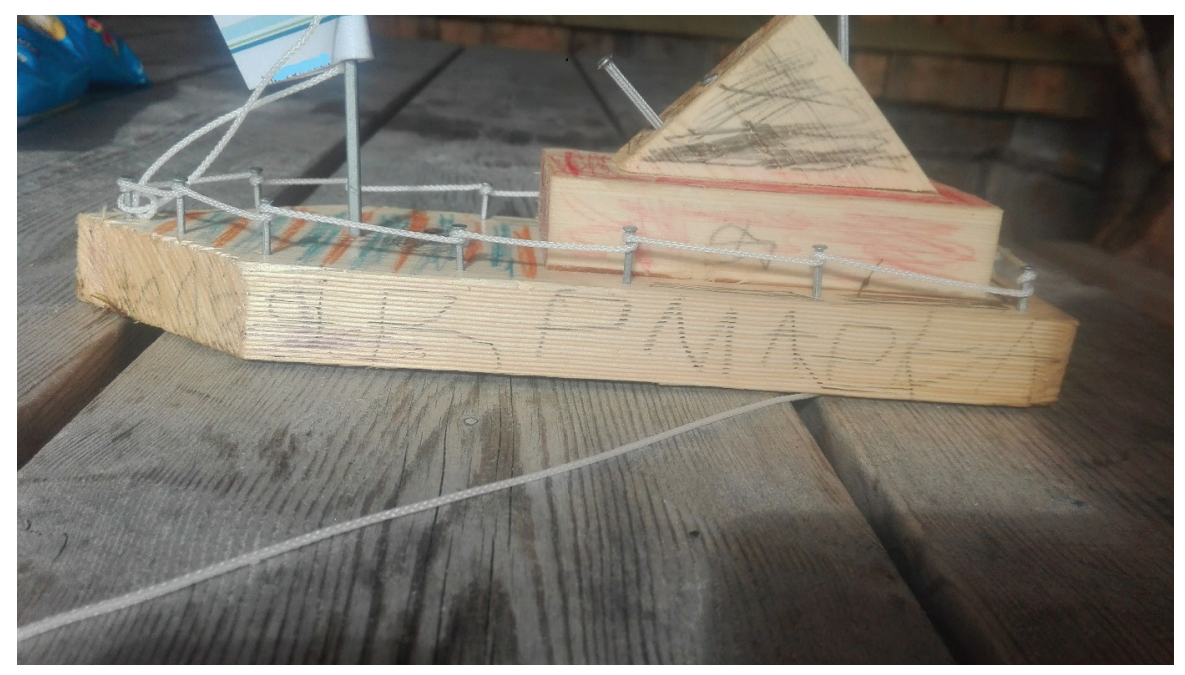

Peter: ЯРМАРКА 


\section{G. K. Fuuhl}

Frå feltnotat:

Så er me klare for å gå. Peter har ein båt som han vil ha med seg. Mor fortel at det er ein plankebåt han har laga i barnehagen eller i ein bursdag, og Peter har skrive namn på båten (sjå bilete). Det er ЯPMAPKA («jarmarka»), eit ord som tyder marknad, messe eller utstilling på russisk. Peter fortel om at på [stadnamn] er det ei bok der me skal skriva namnet vårt. Men så bestemmer han seg for at han ikkje vil til [stadnamn], men til [stadnamn]vatnet. Når me går, les han namna på skilta på turvegen. Vatnet ligg ganske nære. Han har med ei snor som han skal ha i båten, mor hans hjelper med å knyta fast. Så set han båten på vatnet og køyrer litt med han. Han leikar m.a. at båten skyt på nokon med kanonane, og andre ting. Medan han styrer båten snakkar han om kva som skjer i leiken, sånn at han både fortel og er $\mathrm{i}$ leiken og lagar lydane som høyrer med. (Feltnotat, 12.06.2018)

Frå andre besøk hjå Peter veit eg at han har ein kalender med bilete av skip på veggen på rommet, frå firmaet der faren jobbar. Mor fortel også at dei brukar å besøkja bokbåten Epos når den legg til i nærleiken. I den kystkulturelle kvardagen som Peter er ein del av, er døyping av nye, store båtar også hendingar som vert omtala og avbilda $\mathrm{i}$ lokale medium. Peter har altså ein del kunnskap om båtar og tekst på båtar frå kvardagen. Det ser ut til at konvensjonen om at båtar har tekst skrive på øvst på skroget, er ein han deler. Det er grunn til å tru at han også er klar over at namnet til båten vert skrive her. Han er ein femåring som les på ting rundt seg, og han og mora og storesystra snakkar mykje om tekstar.

Båtnamn på skroget kan også forståast som det Miller kallar komplette tekstar, til liks med andre namneskilt og namnelappar. Å gje båten han har laga namnet farmarka og skriva det på sida, er ein del av det å utføra sjangeren namngjeving.

Peter har russiske foreldre, og mor hans held på å læra han å skriva på russisk, mellom anna ved hjelp av lappar på veggen og bokstavaktivitetshefte. Peter held altså på med å tileigna seg lese- og skrivekunsten på norsk og russisk samtidig. I heimen hans er både russisk og norsk skrift godt synleg. Me veit ikkje kvifor Peter valde dette namnet på båten, men å velja eit russisk ord skrive delvis med russiske bokstavar, er ein måte å framheva det russiske språket på ved å gje det ein prominent plass. Det er ei handling som har ein viss retorisitet over seg.

I leiken ved vatnet er ikkje båtnamnet sentralt, men likevel ein aktør som bidreg til å stabilisera denne båten som nettopp denne båten og ikkje ein kva slags som helst plankebåt. Namnet vert ikkje vist til eller framheva, men det er med. Namnet på båten har såleis ein funksjon i det det vert gjeve, og ein annan der det berre bidreg ved å vera ein karakteristikk ved akkurat denne båten, men utan at det er sentralt for handlinga det tek del i, leiken i vatnet.

Også i denne teksten vert det understreka kor skøyr og avhengig av samarbeid mellom aktørar stabiliseringa av tydinga er. Peter har skrive namnet med nokre latinske og nokre russiske bokstavar - mora, som kan båe alfabeta, forstår kva han har skrive, men det er ikkje sikkert ein som berre kunne eitt av alfabeta, hadde fătt tak i denne tydinga. I denne teksten vert også dei ulike alfabeta sin jobb som aktørar synleg. 


\section{Oppsummering og diskusjon}

Analysespørsmåla handla om kva slags meiningsfulle samanhengar desse tekstane inngjekk i, kva slags plass dei hadde i desse samanhengane, og om kva teksten seier. Dei må nok svarast på i samanheng.

Fire av dei fem tekstane set namn på ting, på ulike måtar. Det å namngje er ein meiningsfull aktivitet frå me lærer å snakka til me er vaksne. Namngjeving er mellom dei tidlegast tilgjengelege skriftlege sjangrane for ungar, sannsynlegvis av fleire grunnar: Dei kjenner han frå før i munnleg variant, han kan gjerast med få bokstavar, sin eigen bokstav og sitt eige namn er noko av det fyrste ungar lærer å skriva (Treiman \& Broderick, 1998; Welsch et al., 2003). Å setja namn på ting kan sjåast som eit døme på dei tekstane Karlsson meiner at retorikken bryr seg om: der teksten er sentral i eller utgjer handlinga eller praksisen.

Samstundes inngår alle desse tekstane i samanhengar der namngjeving ikkje er det sentrale. Namneskiltet/husnummeret inngår i huset, som inngår i leiken med og framsyninga av duplohuset. Det er ein aktør på line med lys som kan slåast på og barnedør og vaksendør. Solis-lappen er ein av mange lappar i eit langvarig lappeskrivingsarbeid, Stefani-lappen ein del av rolleleik med dokker, og så ein del av lappesamling og -produksjon. Namnet på båten er ein del av leiken på den måten at namnet er synleg når båten vert leika med, men utan at det vert referert til. I desse samanhengane har kvar tekst ei meir perifer rolle.

Hjartemaskinteksten skil seg ut ved å ikkje vera ein namngjevingstekst, men ved å vera ein leiekartefakt gjennom å vera ein teikna representasjon av eit objekt i verda, nemleg eit kardiogram. Denne typen tekstar kan sjåast på som ein sjangerhybrid exigencen som ligg bak er at ein treng ein ting til leiken, og så lagar ein det, men dei innhaldsmessige og formmessige eigenskapane ved teksten er tekne frå det han er meint å etterlikna.

Til svar på det overordna spørsmålet om kva born brukar tekstar til, har denne undersøkinga stadfest at born brukar tekstar til å namngje, og at den overordna sjangerkunnskapen om namneskilt og namnelappar er brukande og vert brukte $i$ kombinasjon med varierande bokstavkunnskap. Sjangerkunnskapen er ikkje avhengig av full bokstavmeistring for å kunna takast i bruk på ein funksjonell måte. Samstundes er denne funksjonaliteten avhengig av samarbeid mellom aktørar (tekst og menneske) for stabilisering - meir avhengig enn tekstar av meir erfarne skrivarar.

Born brukar også tekstar til å representera (ein kardiograf, eit husnummer) og til å leika. Born sine leike-artefakttekstar er ei utfordring for sjangerteorien fordi me kjenner att eit retorisk behov - behovet for ein artefakt i leiken - medan tekstane som svarer på dette behovet, ikkje treng å ha nokon formmessige likskapar, som jo også er eit kjenneteikn på felles sjangertilhøyrsle. Dette gjer dei til ein type sjangerhybridar.

Dette fortel oss også at to ting femåringar har bruk for i kvardagen sin, og difor brukar tekstar til på eige initiativ, er å setja namn på ting og å attskapa utvalde delar av verda. I tillegg til slike heile tekstar, vart tekst òg brukt til å utforska skriftspråk, 


\section{G. K. Fuuhl}

notera informasjon og å skriva kort/brev. Samstundes fortel studien meir: Om femåringar som fleksibelt og presist handterer sjangrar og situasjonar, noko som gjer at dei kan handtera tekstar som mentale einingar som kan flyttast ut av og inn i nye kontekstar. Samtidig som dei ser ut til å gjera dette pragmatiske arbeidet med lettheit, vert det meir putlete arbeidet som tekstar, skriftspråk og menneske må gjera i lag for å halda ein tekst saman, synleg. Dette stør det Evensen hevdar om at born meistrar det globale ved sjangrar før detaljane i den språklege utføringa (2013, s. 57).

Denne studien fangar ikkje alt ungar i denne alderen brukar tekstar til, men supplerer bilete av borns tekstproduskjon frå anna forsking. Hopperstad analyserer multimodale tekstar av seksåringar som detaljrike og komplekse tekstar (2002). Tekstane i denne studien er i samanlikning i stor grad nedstrippa til den funksjonen teksten utfører. Tekstane Hopperstad samla inn, var laga som resultat av skuleoppgåver der fyrsteklassingar hadde fått i oppdrag å teikna eventyr og andre tekstar, og dei er knytt til skulen si organisering av tid og føremål. Tekstane som denne artikkelen handlar om, er ofte laga raskt, og er eit svar på behov i leiken og/eller knytt til den viktige og grunnleggjande sjangeren å setja namn på ting. Hopperstad får fram uttrykksevna og tydingsmangfaldet $\mathrm{i}$ barn sine teikningar, og viser mellom anna korleis barn fortolkar, attfortel og framhevar sentrale eigenskapar ved tekstar og ting. Denne artikkelen viser samspelet mellom det pragmatiske og teiknmessige arbeidet ungar gjer når dei handlar med tekstar.

Ein del andre studiar av barn sine tidlege tekstar har hevda at det å skriva til andre er noko av det viktigaste born held på med i si tidlege skriving (Evensen, 2013; Lorentzen, 1995, 2009). Å skriva til andre er viktig. Det er likevel slik at det berre dukka opp ein slik tekst i denne studien, eit kort/brev til forskaren. Det er råd å tenkja seg at barn sine brev, kort og teikningar stila til vaksne, har eigenskapar ved seg som inviterer til å leggja merkje til og ta vare på dei, meir enn tekstar som fyrst og fremst har ein funksjon i leiken. Brev har også meir stabilitet i seg sjølv enn skilt på duplohus - ved neste byggjeøkt kan det vera borte. Såleis kan tekst-aktørar sine ulike føresetnader for å ha stabilitet påverka moglegheitene til å verta forskingsobjekt, og $\mathrm{i}$ neste omgang, kva som vert rekna som sanningar og usanningar i forskinga på born sine tekstar.

\section{Forfattarbiografi}

Gudrun Kløve Juuhl er fyrsteamanuensis ved seksjon for norsk i lærarutdanninga på Høgskulen i Volda. Forskingsinteressene hennar er mellom anna barn og vaksne si friviljuge skriving, kvardagstekstar, retorikk og dialogisme.

\section{Referansar}

Asdal, K., Gundersen, T. R., Jordheim, H., Berge, K. L., Gammelgaard, K., Rem, T. \& Tønnesson, J. L. (2008). Tekst og historie: å lese tekster historisk. Oslo: Universitetsforlaget.

Barton, D. (2007). Literacy: an introduction to the ecology of written language. Malden, MA: Blackwell Pub. (Opphaveleg utgjeve 1994.) 


\section{Hjartemaskinar og husnummer}

Barton, D. \& Hamilton, M. (1998). Local literacies: reading and writing in one community. London: Routledge.

Berge, K. L. (2001). Det vitenskapelige studiet av sakprosa. Om tekstvitenskapelige utfordringer og løsninger i norsk og svensk sakprosaforskning. I K. L. Berge, K. R. Breivega, T. Roksvold \& J. L. Tønnesson, Fire blikk på sakprosaen (s. 9-74). Oslo: Norsk sakprosa \& Norsk faglitterær forfatter- og oversetterforening.

Berge, K. L. (2002). Å skape mening med tekst - et etterord om sakprosa og tekstvitenskap. I J. L. Tønnesson (Red.), Den flerstemmige sakprosaen (s. 232-242). Bergen: Fagbokforlaget.

Bitzer, L. (1968). The rhetorical situation. Philosophy $\mathcal{E}$ Rhetoric, 1(1), 1-14. Henta frå https://www.jstor.org/ stable/40236733

Bloodgood, J. (1999). What's in a name? Children's name writing and literacy acquisition. Reading Research Quarterly, 34(3), 342-367. https://doi.org/10.1598/RRQ.34.3.5

Evensen, L. S. (2013). Utvikling eller innvikling? Tidlig skriving før barn møter skolen. I M. Semundseth \& M. H. Hopperstad (Red.), Barn lager tekster. Om barns tidlige tekstproduksjon og de voksnes betydning (s. 47-59). Oslo: Cappelen Damm Akademisk.

Fast, C. (2007). Sju barn lär sig läsa och skriva. Familjeliv och populärkultur $i$ möte med förskola och skola (Doktoravhandling, Uppsala universitet). Henta frå https://www.diva-portal.org/smash/get/diva2:169656/ fulltext01.pdf

Gilje, Ø. (2010). Mode, mediation and moving images: an inquiry of digital editing practices in media education (Doktoravhandling). Oslo: Universitetet i Oslo.

Heath, S. B. (1982). Protean shapes in literacy events: Ever-shifting oral and literate traditions. I D. Tannen (Red.), Spoken and written language: Exploring orality and literacy (s. 91-118). Norwood, NJ: Ablex.

Heath, S. B. (1983). Ways with words: language, life, and work in communities and classrooms. Cambridge: Cambridge University Press.

Heath, S. B., Street, B. V. \& Mills, M. (2008). On ethnography: approaches to language and literacy research. New York: Teachers College Press.

Hoel, T. (2018). «Arne spiller dataspill». Literacypraksiser forut for og utenfor den formelle opplæringen. I M. Rogne \& L. R. Waage (Red.), Multimodalitet i skole- og fritidstekstar (s. 197-208). Bergen: Fagbokforlaget/ LNU.

Hofslundsengen, H. (2017). Betydningen av barns oppdagende skriving $i$ barnehagen. En kvasieksperimentell intervensjonsstudie (Doktoravhandling, Universitetet i Oslo). Henta frå http://urn.nb.no/ URN:NBN:no-66627

Hofslundsengen, H., Gustafsson, J.-E. \& Hagtvet, B. E. (2019). Contributions of the home literacy environment and underlying language skills to preschool invented writing. Scandinavian fournal of Educational Research, 63(5), 653-669. https://doi.org/10.1080/00313831.2017.1420686

Hopperstad, M. H. (2002). Når barns skaper mening med tegning. En studie av seksåringers tegninger $i$ et semiotisk perspektiv (Doktoravhandling). Trondheim: Norges teknisk-naturvitenskapelige universitet.

Hopperstad, M. H. (2013). En toåring maler tekst. I M. Semundseth \& M. H. Hopperstad (Red.), Barn lager tekster. Om barns tidlige tekstproduksjon og de voksnes betydning (s. 29-46). Oslo: Cappelen Damm Akademisk.

Hopperstad, M. H., Lorentzen, R. T. \& Semundseth, M. (2009). Hvilke interesser synes å motivere femåringer til å skrive i barnehagen? FoU $i$ praksis, 3(2), 45-63.

Jæger, H. (2013). Når Vetle lager bildebok ved hjelp av datamaskin. En teksthendelse i hjemmet. I M. Semundseth \& M. H. Hopperstad (Red.), Barn lager tekster. Om barns tidlige tekstproduksjon og de voksnes betydning (s. 116-133). Oslo: Cappelen Damm Akademisk.

Karlsson, A.-M. (2002). Skriftbruk $i$ förändring: en semiotisk studie av den personliga hemsidan. Stockholm: Almqvist \& Wiksell International.

Karlsson, A.-M. (2006). En arbetsdag $i$ skriftsamhället: ett etnografiskt perspektiv på skriftanvändning $i$ vanligayrken. Stockholm: Språkrådet.

Karlsson, A.-M. (2010). I textanalysens utmarker? Om att interessera sig för vad texter gör (och för hur de gör det). I G. Byrman, A. Gustafsson \& H. Rahm (Red.), Svensson och svenskan. Med sinnen känsliga för språk (s. 162-174). Lund: Forfattarane.

Karrebæk, M. S. (2013). Fodboldskort i indskolningen: Literacy, populærkultur og polycentricitet i en minoritetsdrengs hverdagsliv. NordAnd, 9, 9-31.

Kress, G. (1997). Before Writing: Rethinking the Paths to Literacy. London: Routledge. https://doi.org/ $10.4324 / 9780203992692$

Kress, G. \& Van Leeuwen, T. (2006). Reading images: the grammar of visual design. London: Routledge. (Opphaveleg utgjeve 1996). 


\section{G. K. Juuhl}

Latour, B. (2005). Reassembling the social. An introduction to actor-network theory. Oxford: Oxford University Press.

Latour, B. (2008). En ny sociologi for et nyt samfund. Introduktion til Aktør-Netvcerk-Teori. København: Akademisk forlag.

Letnes, M.-A., Sando, S. \& Hardersen, B. (2016). Småbarn og digitale medier 2016. Oslo: Medietilsynet.

Lorentzen, R. T. (1995). To-From. A key to understanding early writing. I Report no. 16 in the publicaton series from the DEVEL Project - Developing written language competence 16-33. Trondheim: Allforsk.

Lorentzen, R. T. (2004). Den vesle skrivaren i det store tekstrommet. I I. Moslet \& P. H. Bjørkeng (Red.), Norskdidaktikk - tekstncer og elevncer undervisning (2. utg., s. 19-28). Oslo: Universitetsforlaget.

Lorentzen, R. T. (2009). Den tidlege skriveutviklinga. I J. Smidt (Red.), Norskdidaktikk - ei grunnbok (s. 113-134). Oslo: Universitetsforlaget.

Matre, S., Sjøhelle, D. K. \& Solheim, R. (2012). Ekspressive tekstar av unge skrivarar: om kjensleutløp, identitetsarbeid og skriveutvikling. I S. Matre, D. K. Sjøhelle \& R. Solheim (Red.), Teorier om tekst $i$ møte med skolens lese- og skrivepraksiser (s. 101-113). Oslo: Universitetsforlaget.

Michelsen, M. (2016). Teksthendelser $i$ barns hverdag. En tekstetnografisk studie av åtte barns literacy og deres meningsskaping på Internett (Doktoravhandling, Universitetet i Oslo). Henta frå http://urn.nb.no/URN: NBN:no-55188

Miller, C. R. (1984). Genre as social action. Quarterly fournal of Speech, 1984(70), 151-167. https://doi.org/ $10.1080 / 00335638409383686$

Purcell-Gates, V. (1996). Stories, coupons, and the TV guide: Relationships between home literacy experiences and emergent literacy knowledge. Reading Research Quarterly, 31(4), 406-428. https://doi.org/10.1598/ RRQ.31.4.4

Schultz, K., Hull, G. \& Higgs, J. (2016). After writing, after school. I C. MacArthur, S. Graham \& J. Fitzgerald (Red.), Handbook of writing research (s. 102-115). New York, London: Guilford Press.

Street, B. V. (1984). Literacy in theory and practice. Cambridge: Cambridge University Press.

Tjora, A. (2017). Kvalitative forskningsmetoder i praksis. Oslo: Gyldendal Akademisk.

Treiman, R. \& Broderick, V. (1998). What's in a name: Children's knowledge about the letters in their own names. Fournal of Experimental Child Psychology, 70(2), 97-116. https://doi.org/10.1006/jecp.1998.2448

Welsch, J. G., Sullivan, A. \& Justice, L. M. (2003). That's my letter!: What preschooler's name writing tell us about emergent literacy knowledge. Fournal of Literacy Research, 35(2), 757-776. https://doi.org/10.1207/ s15548430j1r3502_4

Worthington, M. \& van Oers, B. (2017). Children's social literacy: Meaning making and the emergence of graphical signs and texts in pretence. Fournal of Early Childhood Literacy, 17(2), 147-175. http://dx.doi. $\operatorname{org} / 10.1177 / 1468798415618534$ 